JURNAL SENI MUSIK

\title{
MUSICAL DEVELOPMENT OF BARONGAN TURONGGO LARAS THROUGH ADDITIONAL INSTRUMENTS IN KENDAL REGENCY
}

\section{Cicilia Dikna Astrina Dewi}

Fakultas Bahasa dan Seni, Universitas Negeri Semarang, Indonesia Suharto ${ }^{\bowtie}$

Fakultas Bahasa dan Seni, Universitas Negeri Semarang, Indonesia

\section{Article Info}

Submitted : April, 2021

Revised : May, 2021

Accepted : May, 2021

Keywords:

Accommodation,

Traditional art, Barongan
Abstract

This study aims to determine, describe, and analyze the development of the Barongan work of the Turonggo Laras group in Kendal Regency. The method used is descriptive qualitative with a musicological approach. Data collection techniques include observation, interviews, and documentation. The results showed that the development of working on Barongan Turonggo Laras music was in the form of adding western musical instruments, such as drums and keyboards in collaboration with gamelan. The use of the keyboard is intended as a filler for the main melody in campursari songs. This is because there are tones in the campursari song that does not exist on the gamelan instrument but exist on the keyboard. The addition of drums in the show is intended to lift the mood and strengthen the trance scene. The drum play tends to follow the dynamics of the kendang when accompanying the performance. 


\section{INTRODUCTIONS}

Barongan art is one of the popular traditional arts in Kendal Regency. Almost every village in this district has its barongan group. Some well-known groups from each village are Ngudi Santoso Group in Sumbersari Village, Wahyu Laras Budoyo Group in Tawang Gempol Sewu Village, Margo Rukun Group in Tamangede Village, Rangkah Mudho Group in Puguh Village, Kemangi Group in Jungsemi, Budhaya Mukti Youth Group Sidomukti Village, Krido Singo Manggolo Group Tejorejo Village, and many more (Ali, 2018). The word "barongan" itself according to the KBBI (Indonesian dictionary) is a performing art that resembles a lion that can move because there are people in it (Depdikbud, 2002, p. 109).

Over time, the barongan group not only competed with other barongan groups but also with modern culture. Sri Handayani in her research said that barongan art is seen as an outdated art because people prefer Korean and western culture (Handayani, 2015, p. 3). Among western cultures which are increasingly permeating the nation, it is not easy to maintain regional arts such as barongan (Kussunartini et al., 2009, p. 70). This is because, in its development, globalization has triggered problems in the field of cultures such as the loss of regional culture, the loss of a sense of cultural love, and a westernized lifestyle (Yoga Agustin, 2011, p. 178).

Malinowski said that the entry of foreign culture, especially in the entertainment aspect, is increasingly changing people's tastes. According to Malinowski, a higher and active culture will influence a lower and passive culture through cultural contact (Nahak, 2019). This is exacerbated because these cultures are increasingly accessible through technological developments. Today, many traditional music groups are starting to combine traditional musical instruments with western musical instruments. Sari's research (2019) reveals the art of Patrol Music, which is a combination of gamelan and Marching Band. In the barongan art itself, the amalgamation of western musical instruments with gamelan has been applied by the Kridha Easy Association to the Cepu Barongan. This was later stated by Puspita that three ways can be applied by the association to maintain the existence of barongan art, where one of these ways is to add other modern arts such as keyboards (Puspita et al., 2017).
The Turonggo Laras group is a barongan art group in Kendal Regency that combines traditional musical instruments with western musical instruments. The group added new instruments in the form of drums and keyboards which were then collaborated with gamelan. These two types of musical instruments have different tunings or scales. Western musical instruments use a diatonic scale while gamelan has a pentatonic scale. The combination requires special treatment so that the two types of musical instruments can be in harmony.

\section{METHODS}

This study uses a musicological approach with qualitative descriptive research methods. Primary data sources were obtained from interviews, while secondary data sources in this study were obtained from documentation, both videos, photos, and written sources.

Data collection techniques used are observation, interviews, and documentation studies. In this study, the authors made observations regarding 1) research location, 2) environmental conditions and local communities, 3) Turonggo Laras Group profile, 4) owned facilities and infrastructure, 5) group activity schedule, 6) implementation of coaching or training, and 7) situation and condition when staging. Interviews were conducted with the following informants: 1) to the Chairman of the Turonggo Laras Group 2) to the arranger, and 3) to the people who have watched the group's performances. Additional data the author obtained through the internet, youtube, and documentation belonging to the Barongan Turonggo Laras Group. Analysis and interpretation of research data were carried out using an interactive model consisting of three flows, namely data reduction, data presentation, and concluding (Miles. M, B., \& Huberman, 1994).

\section{RESULTS AND DISCUSSION}

\section{The Form of Barongan Turonggo Laras Art Performance}

The Barongan Turonggo Laras performance is in the form of dances that tell the story of the king of the jungle as a kind-hearted protector. This show contains the appearance of a barongan as the king of the jungle, dawangan resembling genderuwo, jaranan, and rewo-rewo 
which are depictions of cavalry troops, as well as additional performances in the form of a bull and leak. In general, the shows will be performed all day long from morning to evening. Initially, the musicians played the opening songs, including "Suluk Pambuka" and the group's identity song "Turonggo Laras" which was a self-composed song. At the opening, no dance was performed yet. The new group's presentation is in the form of music games and songs only.

Barongan is the first show after the opening has finished playing. It is an imitation of a lion with a costume whose head is made of wood and the body is made of cloth. It is usually filled with two people where one person in front plays a role in moving the barongan's head and the other adjusts. When playing the character, there is a characteristic movement similar to that of an animal opening its mouth to bite something. Usually, there are four barongan that will come out one by one. It has its accompaniment but is usually interspersed with campursari-a mixture of several genres of contemporary Indonesian music- songs.

Besides barongan, dawangan is one of the performances that are no less awaited. At first glance, it is almost similar to the ondel-ondel originating from Betawi. It is a couple of two big figures in the form of a pair of men and women. The head is usually made of wood and the body is made of woven bamboo. It only needs one person to play one character. The most interesting and awaited thing about this show is when the male dawangan will chase the audience who seduces the female dawangan while shaking their hands. Just like barongan, there is a separate accompaniment for dawangan but it uses campursari songs more often.

The use of campursari songs in dawangan performances has its reasons. In the case of barongan and dawangan, which are usually performed more than once in a barongan show, the audience will get bored more easily if the performance is accompanied by the same song over and over again. Campursari songs have a variety of choices and are well known by the public. The lyrics that use the Javanese language that is following everyday life make it attractive to various groups. In addition, the performances of barongan and dawangan are performances that are liked by the public, especially children because dancers can interact directly with them. Thus, campursari songs can be used because they are quite popular and entertaining.
Jaran Kepang is a show that takes a long time to prepare. As the name suggests, players will wear nets complete with vests, headbands and anklets, and flashy make-up. This show focuses more on dances that symbolize someone riding a horse. Usually, the first thing that is shown is the female dancers and then the male dancers follow. Then at the end of the dance, the female and male dancers will dance together in pairs. In the show, the Turonggo Laras Group has their own songs entitled "Jaranan", "Jaran Kepang Putri" and "Jaran Kepang Putra".

In barongan performances, there is always a session where the players will experience a trance or commonly referred to as "ndadi". Ndadi can occur when both male and female players are possessed by spirits so that they lose their consciousness. When the player is being controlled by the spirit, they can perform acts beyond the human mind such as being whipped many times without pain. To overcome the possessed players, usually, there is a special person who can treat them or the term is better known as "nambani". Each trance scene is usually accompanied by campursari songs.

In the barongan show, the trance is the most awaited session for the audience. The trance scene is one of the shows that has its charm and if it is removed it will reduce public attention (Kussunartini et al., 2009). A trance can happen to anyone, both players and audience. However, the attractions that are quite dangerous are only done by professional male players. Female players who are in a trance are usually only more inclined to eat the offerings while still dancing.

\section{The Development of Barongan Turonggo Laras Music}

In barongan art, the addition of new musical instruments to the accompaniment music is one of the ways that can be done as a form of a cultural preservation effort. Puspita explained that three ways can be applied by the group to maintain the existence of barongan art where one of the ways is to add other modern arts such as keyboards. It has been applied by the Kridha Mudha Association to the art of Barongan Cepu so that this art is not forgotten, which brings benefits (Puspita et al., 2017). In addition to Barongan Cepu, Barongan Samin Edan Group in Semarang City has also done the same thing with more diverse instruments including drums, saxophone, string section, and others (Putri \& Arsih, 2019). 
The Turonggo Laras Group is trying to add new musical instruments to the music of barongan art. The following is the background and the form of the addition of new instruments to the music of Turonggo Laras' Barongan art accompaniment:

\section{Background of the Addition of New Instruments to Barongan Accompaniment Music}

Kendal Regency has many barongan groups scattered in almost every village (Priyatin, 2018). Some well-known groups from each village are Ngudi Santoso Group in Sumbersari Village, Wahyu Laras Budoyo Group in Tawang Gempol Sewu Village, Margo Rukun Group in Tamangede Village, Rangkah Mudho Group in Puguh Village, Kemangi Group in Jungsemi Village, Taruna Buddhiya Mukti Group in Sidomukti Village, Krido Singo Manggolo Group, Tejorejo Village, and many more (Ali, 2018). From the many groups, it triggers a great competition among fellow barongan artists. However, as the times progressed, the real rivals of the barongan group were no longer other barongan groups, but a more modern culture that changed people's tastes.

Among western cultures that are increasingly permeating the nation, it is not easy to maintain regional arts such as barongan (Kussunartini et al., 2009). This is because, in its development, globalization has triggered problems in the field of cultures such as the loss of regional culture, the loss of a sense of cultural love, and a westernized lifestyle (Yoga Agustin, 2011, p. 178). It is undeniable that globalization which is spreading so fast is a threat to the existence of local culture (Mubah, 2011). During an increasingly advanced life, there is a little fear that barongan art will someday be seen as an outdated culture and no longer in demand because it is displaced by these new cultures.

The entry of foreign cultures, especially in the entertainment aspect, is increasingly changing people's tastes. According to Malinowski, a higher and active culture will influence a lower and passive culture through cultural contact (Nahak, 2019). This is made worse because the culture is increasingly accessible through technological developments. Through the internet, a person has increasingly diverse choices in finding entertainment media without any limitations of space and time. Call it a variety of video-sharing platforms such as YouTube which provides a variety of content from around the world. At a time when traditional arts are increasingly considered out of date, platforms such as YouTube provide entertainment content that is always new and fresh every day following the times. Not surprisingly, people who are accustomed to contemporary entertainment have begun to forget the traditional arts that have existed before.

At first, the Barongan Turonggo Laras Group only used gamelan instruments as in other barongan performances. The formation of musicians in the arts is usually filled by $9-10$ people according to their respective positions. There is one demung player, two saron players, one bonang player, one drum player, one gong player, one kempul player, one jidor player, and one or two sinden. In the show, the Barongan Turonggo Laras group uses saron and demung with pelog and slendro barrels which will be used and replaced according to the basic tone of the song to be sung, while for the other instruments there is no change. At first, the songs used by the group were also songs commonly found in barongan performances, only for the Barongan Turonggo Laras Group to add homemade songs.

Kobi explained that when times began to change, people's tastes and mindsets also experienced changes. Traditional music is no longer something that is loved by people in modern times (Kobi, 2017, pp. 19-20). The addition of new songs in the Barongan Turonggo Laras show did not change the performance and was less able to attract public interest in an increasingly advanced era. In other words, the barongan art of Turonggo Laras is still considered the same after and before adding a new song. Accompaniment in barongan performances is very important; this is because the movement in barongan art is spontaneous (Septiyan, 2018, p. 191). Call it the movement in barongan and dawangan performances where dancers are free to move and interact with the audience so that the accompaniment music must be able to balance each scene.

Beside the barongan and dawangan performances, the role of accompaniment music is also very necessary in the trance scene. The trance scene is one of the most desirable scenes in a barongan show and requires accompaniment music that can strengthen the atmosphere. In its application, the beginning of the trance scene is usually only accompanied by a campursari song. At the peak of the scene, the song will be stopped and only use the accompaniment whose pattern is repeated. 
The typical accompaniment pattern that is repeated over time gives the impression of a less scary monotone. Thus, there is a need for development in accompaniment music that can give a new impression without losing the original form of the accompaniment and can bring barongan art to the public's interest in an increasingly modern era. In 2016 the thought was born to incorporate western musical instruments into the musical accompaniment of barongan art. In addition to giving a modern impression, the addition of drums and keyboards has their respective functions. The keyboard instrument is intended as an addition to the melody as a variation. Meanwhile, the use of drums aims to lift the atmosphere of the show, especially in the trance scene to make it tenser.

Mr. Su'eb Munthalib, the chairman of the Turonggo Laras Group stated that the addition of new instruments to the group's barongan music was to provide collaboration between traditional music and western music as part of efforts to preserve the culture and tourism of Kendal City. In addition, the development of accompaniment music in the form of adding new musical instruments is also intended to bring traditional arts closer to the community as well as to form the identity of the Turonggo Laras Group so that it is different from most groups in Kendal Regency.

\section{Forms of Developing Barongan Music}

At first, Turonggo Laras Barongan music was the same as most other barongan performances. The musical instrument used is a set of gamelan and the songs that are sung are Javanese songs. It's just that this group is more dominated by new songs composed by themselves. These self-composed songs can be found in almost every session, for example, "Lagu Identitas Turonggo Laras" which was performed at the opening, the song "Jaran Kepang Putri" and "Jaran Kepang Putra" which was used during Jaranan's performance, the song "Bantheng Ketaton" used when performing bulls, and so on. In addition to using their songs, this group also uses campursari songs as variations.

The use of campursari songs in barongan accompaniment can be found in almost every session except the opening. This is because these songs can be inserted anywhere as a distraction. In addition, in cases such as barongan and dawangan performances that can be performed more than once in performance, the audience will get bored more easily if they continue to use the same song. Thus, the campursari song can be the right choice. Also, the lyric in Javanese so that it is easily accepted by the public, this song is quite popular in various circles. As a response to the times, the Turonggo Laras Group added new instruments to its musical accompaniment. Instruments that are added to the barongan accompaniment are western musical instruments in the form of drums and keyboards. Now, the Turonggo Laras Barongan group uses musical instruments Kendang, Demung, Saron, Kempul, Gong Suwukan, Bonang, Jidor, Drum, Keyboard.

The addition of two new instruments in the form of drums and keyboards has its reasons and goals. Based on the narrative of Hadi Handaka as the arranger of the Turonggo Laras Group, he explained that the reason for choosing the keyboard was to fill the main melody in the campursari song because there were notes that were not in the gamelan instrument. campursari is part of Javanese art which is a marriage of traditional music with modern music (Kobi, 2017, p. 11). In its application, the basic tone used for Pelog is Bes = do while Sendro is Gis = do. In addition, the keyboard was chosen because it has a variety of sound options that can be tailored to your needs.

Besides the keyboard, drums are also used in the musical accompaniment of the barongan art of Turonggo Laras but for different reasons and purposes. The use of drums is more intended to strengthen the atmosphere of the show. Based on Hadi's explanation, without drums, the performance will feel less stressful and less crowded. The movements in the barongan and dawangan dances are spontaneous so they require accompaniment music that can follow the dynamics of the player's movements. In addition, what is no less important is the musical accompaniment in the trance dish which is required to be able to strengthen the atmosphere. Thus, drums are the right choice to help support barongan accompaniment music.

One example of a campursari song accompanied by additional drums and keyboards is Prau Layar (Laras Pelog Pathet 6). In campursari songs such as Prau Layar, the keyboard instrument acts as the main melody filler. The accompaniment melody is taken from the original version of the song which can then be developed by the players themselves. The gamelan instrument will adjust the notes on the keyboard. This can be found in the use of tone 4 (pat) to anticipate tone 6 (la) which is not found in gamelan instruments. Figure 1 is an example 
of the use of tones 4 (pat) and 6 (la) in the intro snippet of Prau Layar:

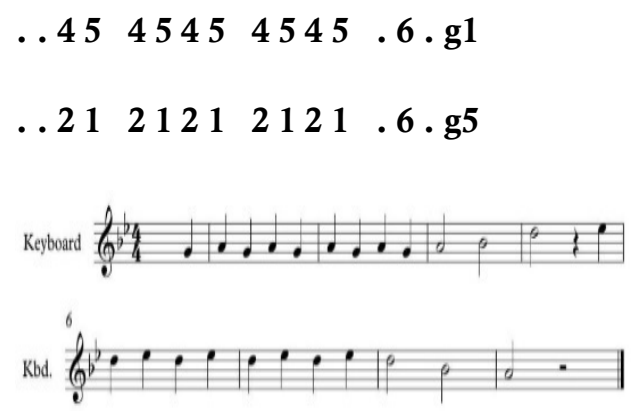

Figure 1. An example of the use of tones 4 (pat) and 6 (la) in the intro snippet of Prau Layar.

Unlike the keyboard, the use of drums is more intended to strengthen the atmosphere of the show. It's just that in practice, the drum does not have a standard accompaniment pattern. As a result, there are often changes in the pattern of accompaniment in the game. This can be found in the changing chorus of Prau Layar's song. As previously explained, the background of the music players who are mostly self-taught makes them free to play as long as the game does not deviate from the song. Although the reading notation is very necessary for playing accompaniment instruments (Nisa, 2013). Beside campursari songs, drums are also used in trance accompaniment to add a more sinister and lively effect. Figure 2 is an example of the use of drums in trance accompaniment:

\section{BALUNGAN}

$6464 \quad 6464 \quad 6464 \quad 646 \mathrm{~g} 4$

\section{DRUM}

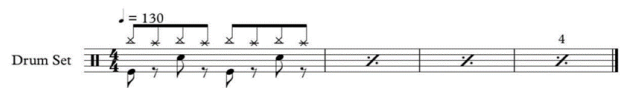

Figure 2. Example of using drums in trance accompaniment

Drumming will follow the dynamics of the drums. When the drumming gets louder, the drumming will also be made more crowded. Usually, the show starts to climax when the players start performing attractions such as being whipped many times, and so on.

\section{CONCLUSION}

Based on the discussion, the Barongan Turonggo Laras at first used gamelan as accompaniment music, just like other barongan groups. However, as the times progressed, the tastes of the people changed. Traditional music is no longer loved and attracts less public interest in modern times. Seeing the changing times and the need for accompaniment music that can support barongan performances, the Turonggo Laras Group added new musical instruments in the form of drums and keyboards to its accompaniment music. The addition of new musical instruments is intended to bring traditional arts closer to society in an increasingly advanced era.

The addition of drums and keyboards to the accompaniment of the Turonggo Laras barongan has its reasons and goals. The reason for choosing the keyboard is as a melody filler in campursari songs. This is because there are tones that do not exist in the gamelan. The keyboard will act as the holder of the main melody and the gamelan adjusts. The basic tone used for pelog is Bes $=$ do while slendro is Gis $=$ do. The use of drums is more intended to strengthen the atmosphere of the show. The movements in the barongan and dawangan dances are spontaneous so they require accompaniment music that can follow the dynamics of the player's movements. In addition, the accompaniment in the trance dish is required to be able to strengthen the atmosphere. Drums can help enliven and build the atmosphere of the show.

\section{REFERENCES}

Ali, S. F. (2018). Kesenian Weleri dalam Seni Barongan. Weleriqu.Blogspot.Com.

Depdikbud. (2002). KAMUS BESAR BAHASA INDONESIA (3rd ed.). Balai Pustaka.

Handayani, S. (2015). Upaya Pelestarian Eksistensi Kesenian Barongan Setyo Budoyo Di Desa Loram Wetan Kecamatan Jati Kabupaten Kudus. Universitas Negeri Semarang.

Kobi, M. F. (2017). Campursari : Bentuk Lain dari Kesenian Gamelan yang Diterima di Masa Modern. Jurnal Warna, 1(1), 120. 


\section{Cicilia Dikna Astrina Dewi/JURNAL SENI MUSIK (10) (1)}

Kussunartini, Dewi, L. N., \& Rukoyah. (2009). Kesenian Barongan Jawa Tengah. Museum Jawa Tengah Ranggawarsita.

Miles. M, B., \& Huberman, A. M. (1994). Qualitative Data Analysis (2nd ed.) (2nd ed.). Sage Publications.

Mubah, A. S. (2011). Strategi Meningkatkan Daya Tahan Budaya Lokal dalam Menghadapi Arus Globalisasi. Journal Unair, 24(4).

Nahak, H. M. . (2019). Upaya Melestarikan Budaya Indonesia Di Era Globalisasi. Jurnal Sosiologi Nusantara, 5(1).

Nisa, I. (2013). Musik Barongan Kelompok Tresna Budaya Dalam Tradisi Ruwatan Di Desa Pasuruan Lor Kecamatan Jati Kabupaten Kudus. Jurnal Seni Musik, 2(1).

https://doi.org/https://doi.org/10.1529 4/jsm.v2i1.2369

Priyatin, S. (2018). Kesenian Barongan, Aset Kendal Menarik Wisman.

Kompas.Com.

Puspita, D. R., Nurhadi, \& Liestyasari, S. I. (2017). Upaya Pelestarian Kesenian
Barongan di Kecamatan Cepu (Studi

Fenomenologi Tiga Paguyuban

Barongan di Kecamatan Cepu

Kabupaten Blora). SOSIALITAS; Jurnal

Ilmiah Pend. Sos Ant, 8(3).

Putri, E. A., \& Arsih, U. (2019). Strategi Adaptasi Kelompok Barongan Samin Edan Kota Semarang Dalam Menarik Minat Penonton. Jurnal Seni Tari, 8(2), 205-215.

Sari, J. R. (2019). Musik Patrol dan Identitas Sosial GAMAN di Surabaya. Resital: Jurnal Seni Pertunjukan, 18(3).

Septiyan, D. D. (2018). Bentuk Pertunjukan Kesenian Barongan Grup Samin Edan Kota Semarang. Jurnal Pendidikan Dan Kajian Seni, 3(2), 180-194.

Yoga Agustin, D. S. (2011). Penurunan Rasa Cinta Budaya Dan Nasionalisme Generasi Muda Akibat Globalisasi. Jurnal Sosial Humaniora, 4(2). https://doi.org/10.12962/j24433527.v4i $\underline{2.632}$ 